\title{
Investigating the levels of teachers' use of student thinking in mathematics classrooms
}

\author{
Bilge Y1lmaz ${ }^{11}$, Ali Bozkurt ${ }^{1}$, and Yusuf Koç ${ }^{1}$ \\ ${ }^{1}$ Gaziantep University, Faculty of Education Department of Elementary, Gaziantep 27100, Turkey
}

\begin{abstract}
In the present study, it was aimed to explore the extent to which teachers' use of student thinking in mathematics classrooms. Two mathematics teachers working at public middle schools participated in the study. One of the teachers had six years of teaching experience and a master's degree in teaching mathematics. The other teacher was an inexperienced teacher with two years of teaching experience. Five lessons of each teacher, ten in total, were video-recorded. Transcripts of the video recordings were analyzed to answer two questions: Do the teachers attend to and remediate student difficulty? and To what extent does each teacher use student thinking? Analysis of the transcripts showed that the teacher with the graduate degree received higher scores with regards to attending to and remediating student difficulty, the second teacher received considerably lower scores on these aspects of teaching. It was observed that the first teacher frequently attended to student thinking and their answers regardless of correctness and made use of his lesson by turning them into an opportunity as well as constructing the target concepts, question types and descriptions. On the other hand, the second teacher failed to take student thinking further rather than using them and sometimes even disregarded their ideas.
\end{abstract}

Keywords: Student thinking, student mistakes and difficulties, mathematics teaching, video analysis

\section{Introduction}

Teaching quality, the skills and knowledge base that teachers should have for an effective teaching, have been discussed and various categorizations have been made [3,11, 17, 22]. What is happening in one's classroom should say much about qualifications and capabilities of a teacher [18]. Several studies on teaching with a focus of teacher-student interaction have been conducted [9, 14]. Classroom discourse is formed through such interactions. Classroom discourse involves verbal and non-verbal communication between students, the teacher and instructional materials [2]. One of the most important aspects in this communication is the way teachers respond to student thinking. Thus, teachers' response is very important with regard to the quality of effective classroom discourse and student thinking as well as their learning $[6,8,20,1]$.

\footnotetext{
${ }^{1}$ Corresponding author: bilqe.yilmaz@gmail.com
} 
When the literature is examined, it is seen that the way teachers respond to and attend to student thinking $[13,7,23]$, and how they use student thinking and create the discourse $[19,10]$ have a critical effect on both the quality of teaching and student learning.

In the present study, it is aimed to explore how the two teachers respond to student ideas including their mistakes, difficulties and opinions and how they used student thinking in teaching. The following questions guided the goals of the study:

1. To what extent do the teachers attend to and remediate student difficulties?

2. To what extent do the teachers make use of student thinking?

\section{Method}

In this case study, the researchers qualitatively describes cases of two mathematics teachers with diverse teaching and education experiences. Mc Millan (2000) describes a 'case study' as a method where one or more cases, environments, programs, social groups or other linked systems are investigated in depth.

\subsection{Participants}

Two mathematics teachers working at different middle schools in Gaziantep participated in the study. One of the teachers, Ismail, had six years of teaching experience and a master's degree in mathematics teaching. The other teacher, Hüseyin, was an inexperienced teacher with two years of experience. In data analysis, Ismail (T1) and Hüseyin (T2).

Table 1. The mathematical content that were taught in the video-recorded lessons and the dates

\begin{tabular}{llll}
\hline Teacher & Lesson & Dates & Content \\
\hline & 1st Lesson & 31.10 .2014 & Prime Numbers \\
Mr. Hüseyin & 2nd Lesson & 31.10 .2014 & Prime Numbers \\
& 3rd Lesson & 05.11 .2014 & Separating a Number into Its Prime Factors \\
& 4th Lesson & 05.11 .2014 & Separating a Number into Its Prime Factors \\
& 5th Lesson & 12.11 .2014 & Common Divisor and GCD \\
\hline & 1st Lesson & 09.10 .2014 & Problem-Solving and Problem-Posing \\
Mr. İsmail & 2nd Lesson & 09.10 .2014 & Multipliers and Floors \\
& 3rd Lesson & 16.10 .2014 & Divisibility by 3 \\
& 4th Lesson & 16.10 .2014 & Divisibility by 4 \\
& 5th Lesson & 20.10.2014 & Divisibility by 6 and Prime Numbers \\
\hline
\end{tabular}

\subsection{Data Collection Process}

Video recordings were used for data collection within the scope of the study. The videoshooting was performed by a professional camera person. Five mathematics lessons (40 minutes each) of the two mathematics teachers' teaching in 6th grade classrooms were recorded. The schools where the two teachers are working are located at low socioeconomic areas. The mathematical content that were taught in the video-recorded lessons and the dates are given in Table 1.

The video-recorded lessons were transcribed. The parts that were difficult to understand due to some reasons (noise, tone of voice etc.) or that could not be heard well were left empty in the transcription. 


\subsection{Data Analysis Process}

Data analysis was handled in two phases. In the first phase, the type of response that mathematics teachers gave about the mistakes and difficulties that students had was investigated. In the second phase, the extent to which teachers considered the mathematical ideas of students that they expressed during the lesson was determined. Two relevant dimensions of the Mathematical Quality of Instruction (MQI; [15] ) measurement tool [15] consisting of 10 dimensions were used for analysis. Mathematical Quality of Instruction (MQI; [15] ) is a measurement tool that aims to find out the mathematical knowledge and sensibility of the teacher concerning mathematical explanations, for teaching and that plays a role in providing information about the teaching and learning based on classroom practices [15]. Each dimension of this tool involves a productive mathematics teaching as a whole and in a balanced way and measures the productivity of mathematics teaching (Hill et al, 2008). In the present study, the codes regarding the extent to which teachers attend to student ideas and low (1), medium (3) and high (5) indicators of each level of the dimensions are as follows:

\subsubsection{Teacher Attends to and Remediates Student Difficulty}

The levels for 'Teacher's attending to and remediating student difficulty' code and the indicators of each level can be seen in Table 2 .

Table 2. The levels for Teacher's attending to and remediating student difficulty code and the indicators of each level [16]

\begin{tabular}{|c|c|}
\hline Levels & Indicators \\
\hline $\begin{array}{l}\text { Low } \\
\text { (1) }\end{array}$ & $\begin{array}{l}\text { A score of } 1 \text { describes lessons in which students' responses indicate that many do not } \\
\text { understand the material, but the teacher does not attempt to remediate. } \\
\checkmark \quad \text { Evidence of student misunderstanding, but teacher does notattend/remediate: } \\
\text { - The teacher does not slow down to remediate } \\
\text { - The teacher may ignore students' incorrect answers or say that they are } \\
\text { wrong without further comment } \\
\checkmark \text { The teacher may fail to respond to students' questions or requests for help } \\
\text { Also score here if teacher attends to difficulty, but the instruction is confusing } \\
\text { or off-track }\end{array}$ \\
\hline $\begin{array}{l}\text { Mid } \\
\text { (3) }\end{array}$ & $\begin{array}{l}\text { A score of } 3 \text { indicates instruction in which the teacher consistently remediates incorrect } \\
\text { student ideas, but only in a brief or pro forma way. For example, the teacher may offer a } \\
\text { simple correction or repeat a question until a student gives the right answer. The lesson } \\
\text { may also include brief instances of more substantial remediation, but for the most part, } \\
\text { remediation is present but minimal. } \\
\checkmark \quad \text { Teacher consistently attends to and remediates, but in a pro forma way, e.g., } \\
\quad \text { correcting errors by asking again until a student gets the correct answer. } \\
\checkmark \quad \text { May include brief instances of more substantive remediation. } \\
\checkmark \text { Also score here if there is no student difficulty. }\end{array}$ \\
\hline $\begin{array}{l}\text { High } \\
\text { (5) }\end{array}$ & 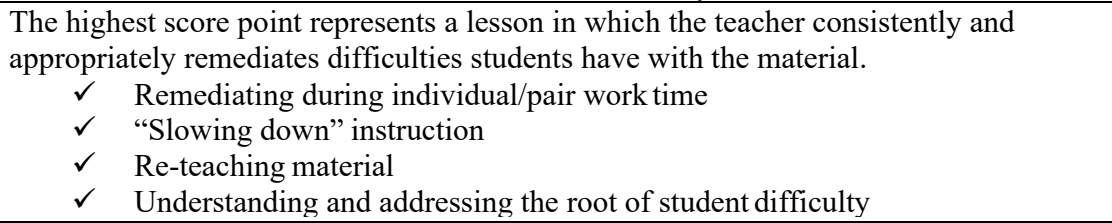 \\
\hline
\end{tabular}

This code aims to find out to what extent teachers attend to and remediate student difficulties in mathematics lessons. 


\subsubsection{Teacher Uses Student Ideas}

The levels for 'Teacher's using student ideas' code and the indicators of each level can be seen in Table can be seen Table 3 .

Table 3. Teacher's using student ideas' code and the indicators of each level [16]

\begin{tabular}{|c|c|}
\hline Levels & Indicators \\
\hline $\begin{array}{l}\text { Low } \\
\text { (1) }\end{array}$ & $\begin{array}{l}\text { A score of } 1 \text { represents a lesson in which the teacher does not use student } \\
\text { ideas to advance the lesson. } \\
\checkmark \text { No teacher use; } \\
\text { - Student talk does not include substantive contributions such as } \\
\text { student explanations or reasoning. OR } \\
\text { - There are some substantive comments, but teacher either } \\
\text { - } \quad \text { Ignores them or } \\
\text { - Teacher use contains errors or confuses the mathematical point }\end{array}$ \\
\hline $\begin{array}{l}\text { Mid } \\
\text { (3) }\end{array}$ & $\begin{array}{l}\text { A score of } 3 \text { indicates a lesson in which there are occasional substantive } \\
\text { student contributions to which the teacher responds appropriately, but the } \\
\text { teacher's responses never go beyond the pro forma level. } \\
\text { - Students contribute an occasional substantive idea to the lesson, } \\
\text { but teacher use is pro forma. For instance: } \\
\text { Acknowledging or endorsing a correct student comment with nothing } \\
\text { further }\end{array}$ \\
\hline $\begin{array}{l}\text { High } \\
\text { (5) }\end{array}$ & $\begin{array}{l}\text { A score of } 5 \text { represents a lesson in which the teacher builds towards the } \\
\text { important mathematical points of the lesson by weaving in student solutions, } \\
\text { explanations, conjectures, or other substantive contributions. } \\
\text { Teacher builds toward the mathematical point(s) of the lesson by } \\
\text { weaving in substantive student contributions and solutions. } \\
\quad \quad \text { Examples include: } \\
\text { - } \quad \text { Compare and contrast different student solution methods } \\
\text { - } \quad \text { Use a student error to uncover a common misunderstanding } \\
\checkmark \quad \text { Levelop a concept by making use of student discussion } \\
\text { - } \quad \text { Teacher re-voicing student contributions for others } \\
\text { - } \quad \text { Elaborating on student contributions } \\
\text { - Selecting specific student contributions to highlight }\end{array}$ \\
\hline
\end{tabular}

This code demonstrates to what extent teacher uses student ideas and solutions to take the lesson further and improve it and thus it becomes possible to find out how often students' make tangible contributions to the lessons and how teacher uses these contributions [15].

In the present study, each video record was coded independently by two researchers for the reliability of scoring, as indicated in Table 1 and 3. A disagreement was found in only 2 of the twenty codings; so, the interrater agreement was $90 \%$. Although this percentage is considered reliable (Miles and Huberman, 1994), the researchers came together one more time and discussed until they reached a $100 \%$ consensus about the evaluation of the two codes where they had disagreements.

\section{Findings}

\subsection{Attending to and Remediating Student Difficulties}

The findings about teachers' attending to and remediating student difficulty are given in 
Table 4.

Table 4. The level of teachers' attending to and remediating student difficulty

\begin{tabular}{lcccccc}
\hline \multirow{2}{*}{ Teacher } & \multicolumn{7}{c}{ Lessons } \\
\cline { 2 - 7 } & $\begin{array}{c}\text { 1st } \\
\text { Lesson }\end{array}$ & $\begin{array}{c}\text { 2nd } \\
\text { Lesson }\end{array}$ & $\begin{array}{c}\text { 3rd } \\
\text { Lesson }\end{array}$ & $\begin{array}{c}\text { 4th } \\
\text { Lesson }\end{array}$ & $\begin{array}{c}\text { 5th } \\
\text { Lesson }\end{array}$ & $\begin{array}{c}\text { Average } \\
(\bar{X})\end{array}$ \\
\hline Mr. İsmail & 5 & 3 & 3 & 5 & 5 & $4.2(84 \%)$ \\
Mr.Hüseyin & 1 & 3 & 3 & 3 & 3 & $2.6(52 \%)$ \\
\hline
\end{tabular}

In Table 4, it is seen that the mean score that Mr.İsmail received in the 'Attending to and Remediating Student Difficulty' code was 4.2 (84\%). The intervention method that he predominantly used in his lessons in order to eliminate the misconceptions that students had and correct the mistakes they made was to ask the class and/or request an explanation for the answers that students give. Also, he first preferred to give them clues about the difficulties they had and then helet another student help. When a student made a mistake, he generally asked the following questions to the entire class or another student: What do you think? Would it be correct? etc. Mr. Hüseyin received a mean score of $2.6(52 \%)$ in this code. It was seen that he mostly chose to disregard student mistakes and preferred to give the correct answer directly in response to student difficulties.

In order to make the findings obtained as a result of the analysis easier to follow, some excerpts from the classroom dialogues in each level (Low, Medium, High) about the 'Attending to and Remediating Student Difficulties' code are given below.

Dialogue-1: (High Level, Mr. İsmail - $5^{\text {th }}$ Lesson)

1 S: So let's say 340. Can we divide 340 by 6 or not? 2 Class: We can.

$3 \mathrm{~T}$ : Who wants to try?

4 S7: It's possible to

divide. 5 T: You say so

(S7)?

6 S7: Yes.

7 T: What's your basis for that?

$8 \mathrm{S7}$ : The last digit is a multiple of 6. It's zero.

$9 \mathrm{~T}$ : The last digit is a multiple of 6 ?

\section{S8: Yes, the last two digits}

11 T: Pardon?

12 S8: The last two digits are a multiple of 6.

13 T: So, does it matter if the last two digits are a multiple of 6? 14 Class: No.

$15 \mathrm{~T}$ : Alright, take it easy! So, is the number divisible by 6 , when the last two digits are a multiple of 6 ? Is there such a rule? For example, let's take 112 - the last two digits are a multiple of $6 \ldots$

16 Class: Yes

17 T: Is 112 divisible by 6 ? 
18 Class: Yes, it is.

19 T: Is it? Shall we see? Let's divide! In 11, there is a multiple of 6 - so, when we extract we get a remainder of 5 .

20 Class: Yes

$21 \mathrm{~T}$ : There is no multiple of 6 in 5. In 52, we have 8 times 6 . We subtract 48 from 52.

22 S9: It leaves a remainder of 4 . So, it's not divided evenly.

$23 \mathrm{~T}$ : So, it is not about the last two digits? I did not tell you about such a rule anyway. So, what's the divisibility rule for 6 ?

In the lesson when the divisibility rule for 6 was taught, Mr. İsmail expected his students to make generalizations based on the examples about divisibility by 6 . In this regard, he asked whether 340 was divided evenly by 6 and the class said yes. As it's seen in Dialogue 1 , the teacher chose to correct the mistake that students made about divisibility by 6 (line 8,10 ) by giving another example that would indicate the students' mistake (like 17, 23). In the script given above, it is striking that the teacher asked for an explanation for the wrong answer that students gave (Line 7) and chose to correct it based on the reason/basis they told.

Dialogue-2: (Mid-Level, Mr. Hüseyin - $2^{\text {nd }}$ Lesson)

1 S18: Teacher, can I ask you something?

$2 \mathrm{~T}$ : (He nods)

3 S18: We know that the smallest prime number is 2 but we can't know the largest one, right?

4 T: Yes, we can't know.

\section{S19: It's 97.}

\section{$6 \mathrm{~T}$ : No, 97 is the largest two-digit prime number.}

When students asked whether the numbers written on the board as an example were prime numbers or not, the teacher asked what the smallest prime number was and how many even prime numbers there were in the Prime Numbers Table up to 100 in their course book before Dialogue 2, in the lesson when the teacher gave some information about prime numbers. In Dialogue 2, a student claimed that the largest prime number was 97 (line 5) and then, the teacher just said it was not (Line 6) but did not make a detailed explanation about it.

Dialogue-3: (Low Level, Mr. Hüseyin, $1^{\text {st }}$ Lesson) 1

S36: It's 30 .

2 T: It says between 20 and 30,

\section{S37: But teacher, it said 'the last two tickets' and we found that.}

$4 \mathrm{~T}$ : The tickets ending with 23 and 29 win the prize. Now, let's continue with the other example.

In the exchange, the teacher asked students to find the prime numbers between 20 and 30 with the following question: "The last two digits of two lottery ticket that won a prize are between 20 and 30 and these numbers are evenly divisible by themselves and 1. Find the last two digits of the tickets that won the price based on these clues." As it is seen on Dialogue 3, Student 37 (Line 3) thought that they would be the last two tickets as he/she could not understand the question well and even though he expressed this, the teacher did not make any attempt to correct this mistake - he did not even realize. 


\subsection{Using Student Ideas}

The findings concerning 'using student ideas' code that we handled to see how teachers use student ideas are given in Table 5.

Table 5. The levels of teachers use student ideas

\begin{tabular}{lcccccc}
\hline & \multicolumn{7}{c}{ Lessons } \\
\cline { 2 - 7 } Teacher & $\begin{array}{c}\text { 1st } \\
\text { Lesson }\end{array}$ & $\begin{array}{c}\text { 2nd } \\
\text { Lesson }\end{array}$ & $\begin{array}{c}\text { 3rd } \\
\text { Lesson }\end{array}$ & $\begin{array}{c}\text { 4th } \\
\text { Lesson }\end{array}$ & $\begin{array}{c}5 \text { th } \\
\text { Lesson }\end{array}$ & $\begin{array}{c}\text { Average } \\
(\bar{X})\end{array}$ \\
\hline Mr. İsmail & 5 & 5 & 5 & 5 & 5 & 5 \\
Mr. Hüseyin & 3 & 3 & 3 & 1 & 3 & 2.6 \\
\hline
\end{tabular}

In Table 5 , it is seen that Mr. İsmail received a mean score of $5(100 \%)$ about 'using student ideas' code in all his lessons. He always attended to the ideas and answers of his students regardless of whether they're right or wrong, turned them into opportunities to teach.

As for Mr. Hüseyin, the mean score in his lessons was $2.6(52 \%)$. It was seen that students contributed in only $30 \%$ of all his lessons, with a tangible mathematical idea. Students only responded to the Yes/No questions that the teacher asked. Other than that, Mr.Hüseyin did not take these ideas further (sometimes just nodded, smiled etc.) to improve their learning and sometimes even ignored them, rather than using student ideas in the lessons when students actually contributed with tangible ideas, solutions etc.

In order to make it easier to understand the findings obtained as a result of the analysis, some examples from classroom dialogues for each level (Low, Medium, High) concerning the 'using student ideas' code are given below.

Dialogue-4: (High Level, Mr. İsmail - $2^{\text {nd }}$ Lesson)

$1 \mathrm{~T}$ : What does 'multiples' mean? What does it mean to be 'a multiple of a number'? 2 S33: multiples of two

$3 \mathrm{~T}$ : What do you mean?

4 S33: 2, 4, 6, 8, 10.

$5 \mathrm{~T}$ : So which number are $2,4,6,8,10$ multiples of? 6 S33: They are multiples of 2.

7 T: Multiples of 2? So, listen: Your friend says 2, 4, 6, 8, 10 are multiples of 2. Is that correct? So how can we define a 'multiple' of a number? What does it mean when they say 'multiples of 5' for example?

8 S34: 5 multiplied by 2

9 T: Only 5 multiplied by 2? Can we not say 5 multiplied by

10? 10 Class: We can.

11 Ö: 5 multiplied by

7? 12 Class: Yes, we can.

$13 \mathrm{S35}$ : So, it is 5101520.

$14 \mathrm{~T}: 5,10,15,20$ ? 
15 S35: Teacher, 5 multiplied by 2 equals 10 (we multiply the first number by 2)

$16 \mathrm{~T}$ : Do you agree with him? (He asks another student)

17 S36: Yes, he's right.

18 T: Is he right? Listen... When we say 'multiples of 5' we mean all the number we get when 5 is multiplied by any number. For example, we get 35 when 5 is multiplied by 7 35 is a multiple of 5 .

We get 10 when we multiply 5 by 2 -- 10 is a multiple of 5 , right?

5 itself is a multiple of 5 - 5 multiplied by 1 . Then we can multiply 5 by 3 - it equals 15 .

Am I right?

In this lesson when the concepts of 'multiplier' and 'multiple' were discussed, the teacher asked his students what they meant. The teacher used the answers they gave (Line 1) in order to define these mathematical concepts. As it is seen in Dialogue 4, he tried to teach them the concept of 'multiple' based on the tangible examples (Line 4,13) that students gave.

Dialogue- 5: (Mid-Level, Mr. Hüseyin $-2^{\text {nd }}$ Lesson)

1 T: ... So, is 8 a prime number?

2 Class: No, it's even.

3 T: But 2 is even, as well?

4 Class: (everyone talks at the same time).

5 T: Please, can you speak one by one?

6 S6: 2 is the only even prime number.

$7 \mathrm{~T}$ : (He nods) Right. What is the largest prime number?

As it is seen in Dialogue 5, the teacher responded only by nodding to the idea of S6 who said that there was no even prime number other than 2 and the teacher did not underline an important mathematical point that there cannot be any other even prime number other than 2 , using the student's idea.

Dialogue- 3: Low Level (Mr. Hüseyin - $2^{\text {nd }}$ Lesson)

In the lesson when only two operational problems were worked on in order to find the prime multipliers of 20 and 72, the teacher did not use any student idea as the students did not share a tangible idea whatsoever during the progress of the lesson. In the lesson, it was seen that the students responded to Yes/No questions asked by the teacher but did not share any mathematical idea individually.

\section{Discussion}

In the present study, it was aimed to find out to what extent teachers attend to and remediate student difficulties in mathematics lessons and to what extent they make use of student opinion. As a result of the study where 5 lessons of each teacher were evaluated, it was found out that the lessons given by Mr. İsmail are of a higher level in comparison to those given by Mr. Hüseyin.

When it comes to the extent teachers attended to and remediated student difficulties and mistakes, it was seen that Mr. İsmail was always sensitive about the difficulties students had and made an effort to eliminate them. He asked the reasons for his students' answers and wanted them to give justifications regardless of whether their solutions and 
answers were correct. As for Mr. Hüseyin, it was striking that he disregarded the challenges and difficulties that students experienced and/or just evaded them with a smile. Also, the explanations he sometimes made with regards to the challenges students had were not detailed.

In the studies focusing on the reactions teachers give about the difficulties and challenges that students experience in the lesson, it is seen that teachers generally ask for an explanation for student's answer; ask the question to the class; criticize; give the correct answer; repeat the question; laugh or just disregard [4, 7, 12, 21, 24]. It may be difficult for teachers not to remain unresponsive to the difficulties and mistakes of students in the lesson, to slow down the pace of the lesson and give detailed explanations and examples so that the challenging points can be understood. However, it is important that meaningful learning is achieved while students learn different ways of thinking and teachers present the content they want to teach by turning such situations into an opportunity. In this regard, it is seen in the literature that the type of intervention a teacher uses has an effect on students' ways of thinking [7, 13]. Thus, it can be said that the results of teachers' attending to and remediating student difficulties or just disregarding them affect students' learning, thinking as well as classroom interactions.

When we consider the extent teachers used student ideas, it can be said that Mr. İsmail gave opportunities to his students to form the rules (divisibility rules etc.) based on the examples given in the lesson and used their ideas. With regards to different solution methods or views, he generally asked other students their opinion. As for Teacher Hüseyin, it was seen that students contributed only in one-third of the lesson, with a tangible mathematical idea. Students responded to only Yes/No questions asked by the teacher. Other than that, Mr. Hüseyin did not take students' ideas further (just nodded, smiled etc.) when they actually contributed to the lesson and sometimes disregarded their ideas rather than using them. However, it is known that teacher-student interactions and sharing during the lesson shape students' learning [5, 25]. Also, researches demonstrate the effectiveness of a teaching that attends to general misconceptions, misunderstanding, number choices, solution strategies of students etc. and where the mathematical ideas that students form are put at the center [5,23].

In summary, Mr. Ismail achieved a higher level with regards to using student ideas in comparison to Mr. Hüseyin. This finding forms the opinion that teachers' education level and years of service in teaching were influential in their using students' ideas in classroom activities. From this perspective, students getting lessons from teachers with a higher degree of education and more experience in teaching can be considered lucky. It is important that teachers are raised/trained well in terms of qualifications and capabilities, and deficiencies, if there is any, should be found out and eliminated so that students are not at a disadvantage in their education process in terms of teacher factor.

\section{References}

1. Alajmi, A., \& Reys, R. (2007). Reasonable and reasonableness of answers: Kuwaiti middle school teachers' perspectives. Educ. Studies in Mathematics, 65(1), 77- 94.

2. Ball, D. (1991). Research on teaching mathematics: Making subject-matter knowledge part of the equation. In J. Brophy (Ed.), Advances in research on teaching, a research annual: Teachers' knowledge of subject matter as it relates to their teaching practice (pp. 1-48). Greenwich, CT: JAI Press. 
3. Bozkurt, A.(2011). A classroom observation-based evaluation of elementary teachers use of technology in the classrooms in Turkey. Educational Research and Reviews, 6(4), 367-373.

4. Bozkurt, A. (2012). Ortaöğretim Öğretmenlerinin Sınıflarında Oluşturmaya Çalıştıkları Öğretim Normları ve Bu Normların Bazı Değişkenlere Göre İncelenmesi. Ahi Evran Üniversitesi Kırşehir Eğitim Fakültesi Dergisi, 13(2) [In Turkish].

5. Carpenter, T. P., Fennema, E., Peterson, P. L., Chiang, C. P., \& Loef, M. (1989). Using knowledge of children ${ }^{\text {ee }}$ mathematics thinking in classroom teaching: An experimental study. American educational research journal, 26(4), 499-531.

6. Chapin, S. H., \& Anderson, N. C. (2003). Crossing the bridge to formal proportional reasoning.

7. Chick, H. L., \& Baker, M. K. (2005). Investigating Teachers 'responses to Student Misconceptions. Conference on International Group for the Psychology of Mathematics Education, 249.

8. Chin, C. (2006). Classroom interaction in science: Teacher questioning and feedback to students' responses. International Journal of Science Education, 28(11), 13-15.

9. Cohen, D. K., Raudenbush, S. W., \& Ball, D. L. (2003). Resources, instruction, and research. Educational evaluation and policy analysis, 25(2), 119-142.

10. Dekker, R., \& Elshout-Mohr, M. (2004). Teacher interventions aimed at mathematical level-raising during collaborative learning. Educational Studies in Mathematics, 56(1), 39-65.

11. Demir, S., \& Bozkurt, A. (2011). İlköğretim matematik öğretmenlerinin teknoloji

12. entegrasyonundaki öğretmen yeterliklerine ilişkin görüşleri. İlköğretim Online,10(3) [In Turkish].

13. Drews, D. (2005). Children's mathematical errors and misconceptions: perspectives on the teacher's role. Children errors in mathematics: Understanding common misconceptions in primary schools, 14-21.

14. Hiebert, J., Gallimore, R., Garnier, H., Givving, K. B., Hollingsworth, H., Jacobs, J., et al. (2003). Teaching mathematics in seven countries: Results from the TIMSS 1999 video study. Washington, DC: National Center for Education Statistics.

15. Hiebert, J.,\& Grouws, D. A. (2007). The effects of classroom mathematics teaching on students $^{\text {ee }}$ learning. Second handbook of research on mathematics teaching and learning, 1, 371-404.

16. Hill, H. C., Blunk, M. L., Charalambous, C. Y., Lewis, J. M., Phelps, G. C., Sleep, L., \& Ball, D. L. (2008). Mathematical knowledge for teaching and the mathematical quality of instruction: An exploratory study. Cognition and instruction, 26(4), 430-511.

17. Hill, H. C. B. (2010). Measuring the mathematical quality of instruction. Journal of Mathematics Teacher Education.

18. Hofer, M. ve Swan, K.O. (2008). Technological pedagogical content knowledge in action: A case study of a middle school digital documentary project. Journal of Research on Technology in Education, 41(2), 179-200.

19. Kane, T.J., \& Staiger, D.O. (2012). Gathering Feedback for Teaching: Combining High-Quality Observations with Student Surveys and Achievement Gains. Research Paper. MET Project. Bill \& Melinda Gates Foundation.

20. Lustick, D. (2010). The priority of the question: Focus questions for sustained reasoning in science. Journal of Science Teacher Education, 41(5), 495511.Mathematics Teaching in the Middle School, 8(8), 4-20.

21. Morge, L. (2005). Teacher-pupil interaction: A study of hidden beliefs in conclusion phases. Research report. International Journal of Science Education, 27(8), 9-35.

22. Santagata, R. (2005). Practices and beliefs in mistake-handling activities: A video study of Italian and US mathematics lessons. Teaching and Teacher Education, 21(5), 
491-508.Shulman, L.(1986). Those who understand: Knowledge growth in teaching. Educational Researcher, 15(2), 4-14.

23. Stein, M.K., Smith, M.S., Henningsen, M.\& Silver, E.A. (2000). Implementing standarts-based mathematics instruction: A casebook for Professional development. New York: Teachers College Press.

24. Swan, M. (2001). Dealing with misconceptions in mathematics. In Gates, P. (Ed). Issues in Mathematics Teaching. Routledge Palmer: London

25. Van den Oord, E. J., \& Rossem, V. (2002). Differences in first graders' school adjustment: The role of classroom characteristics and social structure of the group. Journal of School Psychology, 40(5), 371-394. 